\title{
EFFECT OF USING SWEET POTATO AND POTATO FLOURS ON PHYSICAL, CHEMICAL AND SENSORY PROPERTIES OF SPONGE CAKE
}

\author{
Magda R.Abd El-baki \\ Food Science and Technology Dept., Fac. Agric., Fayoum Univ., Egypt. \\ ABSTRACT \\ Sponge cake was prepared by replacement sweet potato and \\ potato flours (refused small size) at levels 10, 20 and 40\%. Chemical \\ composition of sweet potato and potato flours showed that sweet potato \\ had lower moisture and fiber contents. $\beta$ - carotene content, increased \\ from 12 to 30 and $40 \mathrm{mg} / 100 \mathrm{~g}$ when sweet potato was incorporated \\ from 0 to $40 \%$ into the sponge cake formulation. Farinograph readings \\ indicated that water absorption increased significantly from $58.2 \%$ to \\ $65 \%$ with increase sweet potato flour to $40 \%$. Resistance to extension \\ values are increased with increasing the sweet potato to $10 \%$ and \\ decreased at the other levels. Regarding physical characteristics of \\ sponge cake, results revealed that sweet potato flour at levels $10 \%$ and \\ $20 \%$ caused increase in sponge cake volume. Also, the specific volume \\ of sponge cake increased with each increase of substitution. On the \\ other hand, it was noticed that, organoleptic scores of sponge cake \\ supplemented with sweet potato at level $20 \%$ and potato flour at $10 \%$ \\ increased, otherwise there was no significant differences between \\ control and supplemented sponge cake. The results showed also that \\ sweet potato and potato flours had antimicrobial effect .In general, the \\ overall acceptability of sponge cakes was improved by $20 \%$ sweet \\ potato and $10 \%$ potato flours substitution.
}

Key words: sweet potato, potato flour, $\beta$ - carotene, total phenol, sponge cake batter, organoleptic evaluation.

\section{INTRODUCTION}

In most developing countries, wheat production is limited and wheat must be imported to meat local demand. Sweet potato (Ipomoea batatas) and potato (Solanum tuberosum L.) which belongs to the family Convolvulaceae are naturally gluten- free has been widely cultivated for centuries in various geographic regions. The prevalence of celiac disease, an intolerance of gluten, has been reported to be as high as one in 200 of the world population (Fasano \& Catassi, 2001). The majority of those diagnosed with this disease are silent and latent cases, which have the potential but may or may not develop the disease (Feighery, 1999). Sweet potato has been used as food and herb in many countries (Yin et al., 2008). Sweet potato and potato can be processed into flour and can partly substitute for wheat and other cereals flours, and enrich $B$ carotene content in bakery products. It is an economical and healthful food crop that has been widely grown in many parts of the world. Sweet potato, in which vitamin $\mathrm{C}$, chlorogenic acid, caffic acid, quercetin and rutin are abundant, is one of the functional food products aimed at introducing human dietary ingredients that aid specific body functions in addition to being nutritionous (Guan $\boldsymbol{e t}$ al.,

Fayoum J. Agric. Res. \& Dev., Vol.22, No.2, July, 2008 
2006). It is the world's seventh most important food crop after wheat, rice, maize, potato, barley and cassava (Woolke, 1990, Ray \& Ravi, 2005). The sweet potato tubers are rich in starch, sugars, vitamin C, provitamin A, iron and minerals (Woolfe, 1992 and Ray \& Ward, 2006). The colored varieties contain pigments: ß-carotene, anthocyanin and unidentified flavonoids (Yamakawa, 1998). These pigments are regarded as antioxidants having several physiological attributes such as antioxidation, anticancer, anti-immunodilation and protection against cataract, ageing, macular degeneration, liver injury (Mayne, 1996, Bohm et al., 1997 and Yamakwa, 1998). Night blindness is a major physiological disorder among rural and tribal people in many developing and undeveloped countries (Woolfe, 1992 and Kays \& Kays, 1998) because of vitamin A deficiency, at the same time, more and more modern research has shown that sweet potato has antimicrobial, antihypertensive activities and has ultraviolet protection effects (Jansson \& Raman, 1991, Woolfe, 1992, Zhan, 1996, Yoshimoto et al., 1999, Yoshimoto, 2001, Yoshimoto et al., 2001, Oki et al., 2002, Matsui et al., 2002, Cevallos-Casals, 2003 and Cambie \& Ferguson, 2003).

Sponge cake is one of the most important energy foods in human diet. The specific objectives of this study were, to formulate cakes supplemented with vary levels of sweet potato and potato flours and evaluate proximate composition, Bcarotene ,vitamin $\mathrm{C}$, cake volume and moisture loss during 10 day storage period and to characterize the sensory properties of the cake .

\section{MATERIALS AND METHODS}

Materials

Refused (small size) sweet potato tubers with deep orange flesh, potato tubers and wheat flour (72 \%) were purchased from local supermarket in Fayoum, Egypt. Sweet potato tubers and potato tubers were washed and converted into flour using the following procedure:

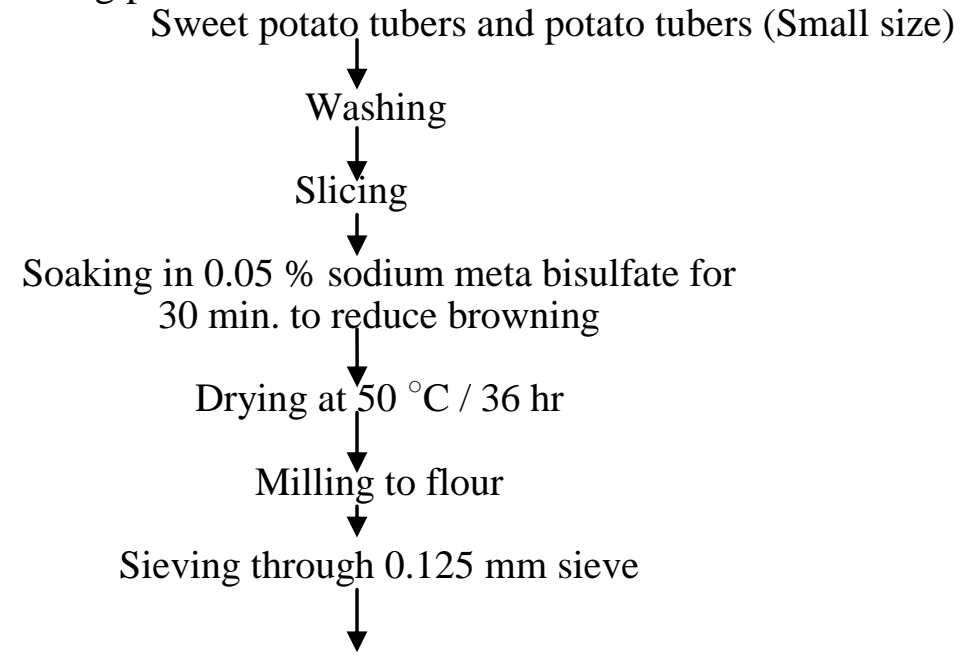

Packing in poly ethylene pages and stored at room temperature $\left(35 \pm 2{ }^{\circ} \mathrm{C}\right)$ Fig. (1) Flow chart for production of sweet -potato and potato flours

Fayoum J. Agric. Res. \& Dev., Vol.22, No.2, July, 2008 


\section{Preparation of sponge cakes}

Sponge cakes were prepared according to (Celic et al., 2007) with slight modification as follows:

The recipe in Table (1) was used; wheat flour was replaced with sweet potato and potato flours at levels of $10 \%, 20 \%$ and $40 \%$. Egg and sugars were whipped to a cream for $4 \mathrm{~min}$. Then, flour and baking powder were added into the mixture, and it was whipped at medium speed for two minutes. Finally, equal amount of batter $(130 \mathrm{~g})$ were poured into pans $(8.5 \mathrm{~cm}$ length, $5.3 \mathrm{~cm}$ width and $9.3 \mathrm{~cm}$ height) and baked at $180{ }^{\circ} \mathrm{C}$ for $25 \mathrm{~min}$., sponge cakes were allowed to cool at room temperature. They were carefully taken out of the pans and placed in polyethylene bags and stored in dry and cool environment prior to analysis.

Table 1: Sponge cake formula

\begin{tabular}{|l|c|}
\hline \multicolumn{1}{|c|}{ Ingredient } & \% \\
\hline Flour $(72 \%)$ & 33.00 \\
\hline Egg & 31.00 \\
\hline Sugar & 32.00 \\
\hline Baking powder & 3.00 \\
\hline Vanillin & 0.50 \\
\hline Salt & 0.50 \\
\hline
\end{tabular}

\section{Analytical methods}

Sweet potato flour, potato flour, wheat Flour $(72 \%)$ and sponge cake were analyzed for moisture, protein, ash, crude fiber, ether extract contents, ascorbic acid and $\beta$ - carotene, according to AOAC, (2000). Reducing and non reducing sugar were determined according to Lane \& Eynon (AOAC, 2000) method. Nitrogen free extract was calculated by difference.

\section{Total phenol content}

Raw materials (wheat flour $72 \%$ ext., sweet potato, potato flours) and sponge cakes prepared from $0 \%, 10 \%, 20 \%$ and $40 \%$ sweet potato and potato flours were analyzed for total phenol content. One $\mathrm{g}$ of defatted sample (after refluxing with chloroform and petroleum ether, $(1: 1 \mathrm{v} / \mathrm{v})$ followed by drying) was mixed with $10 \mathrm{ml}$ of water for aqueous extraction (WE). Similarly for methanol extraction (ME), stirred and centrifuged at 2000 r.p.m.for 15 min. The above supernatants were referred as water extract (WE) and methanol extract (ME), respectively. The total phenolic contents of the WE and ME were determined colorimetrically using the Folin- Cicolteau method (Singleton et al., 1999). The absorbance was measured at $765 \mathrm{~nm}$. The total phenolic content was expressed as milligram tannic acid equivalent (TAE) per gram sample.

\section{Dry gluten}

Dry gluten was determined in the wheat flour blends (were prepared by replacement sweet potato and potato flours at levels 10, 20 and 40\%) according to the method given in A.A.C.C., (2000).

Fayoum J. Agric. Res. \& Dev., Vol.22, No.2, July, 2008 
Rheological properties

The effect of sweet potato and potato flours substitution on the mixing and the elastic properties profile of the dough were studied using farinograph and extensograph according to the standard A.A.C.C., (2000). Specific gravity of cake batters was determined by the method of Lee and Hoseney (1982). pH values of cake batters were monitored with a $\mathrm{pH}$ meter.

\section{Physical measurements of sponge cake}

After the sponge cake was cooled to room temperature, it was taken out of the cake pan and weighed to calculate the baking loss as follows:

Baking loss $(\%)=(1-($ cake weight $/$ batter weight $)) \times 100$

Volume $\left(\mathrm{V}, \mathrm{Cm}^{3}\right)$ of sponge cake was measured using clover seed displacement method. Weight of the cakes was measured $(\mathrm{W}, \mathrm{g})$ and density was calculated by ratio of cake volume to cake weight.

\section{Storage studies}

Sponge cakes samples packaged in polyethylene bags and sealed were marked for $0,2,4,6,8$ and 10 days of storage at room temperature $\left(35 \pm 2{ }^{\circ} \mathrm{C}\right)$. These samples were analyzed daily for moisture.

\section{Microbiological examination}

Total plate count (TPC) and the total mold and yeast medium were used for detecting the microbial count according to the methods described by Julseth $\boldsymbol{\&}$ Deible (1974)

\section{Organoleptic evaluation}

The organoleptic evaluation of cakes was carried out, using a panel taste according to Mostafa, (1976). The panelists were asked to evaluate the cakes for shape, crust color, crust appearance, crumb color, texture, grain cell structure, odor and taste.

\section{Statistical analysis}

Analysis of variance was computed using the general linear model (GLM) procedure of statistical analysis system (SPSS, 1999). Differences among means were evaluated using Duncan's multiple range test (Duncan, 1955).

\section{RESULTS AND DISCUSSION Chemical composition}

The mean values of proximate composition (moisture, ether extract, protein, crude fiber, ash and nitrogen free extract) of sweet potato flour, potato flour and wheat flour (72\%) samples are presented in Table (2). Data show the wheat flour had high amount of moisture $(13.64 \%)$ followed by potato flour $(5.17 \%)$ and sweet potato flour $(4.14 \%)$. As concerning protein content it is observed that wheat flour had high percentage of protein $(11.36 \%)$ followed by sweet potato flour $(6.86 \%)$ and potato flour (1.99\%). Most cereal flour contains, except wheat flour, less than $9 \%$ protein. These results are in agreement with the range of these components reported by Tian et al., (1991). Reducing, non reducing and total sugars content are given in Table (3). Reducing sugars contents in sponge cake were increased in supplemented sponge cake with sweet potato or potato flour compared to control. The increasement was observed

Fayoum J. Agric. Res. \& Dev., Vol.22, No.2, July, 2008 
EFFECT OF USING SWEET POTATO AND POTATO FLOURS ON... 169 proportionally with the increase in level of substitution. As the sweet potato and potato tuber were not peeled before drying; the flour had a relatively high level of crud fiber. The largest analytical component in sweet potato and potato flour was the NFE, which, it can be supposed, was mainly starch in tuber. These results are in agreement with (Afookwa \& Sefa- Dedeh, 2001and Hsu et al., 2004).

Table (2): Chemical composition of wheat, sweet potato and potato flours*

\begin{tabular}{|l|c|c|c|}
\hline $\begin{array}{c}\text { Parameter } \\
\text { \% }\end{array}$ & Wheat flour (72\%) & Sweet potato flour & Potato flour \\
\hline Moisture & $13.64 \pm 0.65^{\mathrm{a}}$ & $4.14 \pm 0.06^{\mathrm{b}}$ & $5.17 \pm 0.05^{\mathrm{b}}$ \\
\hline Protein & $11.36 \pm 0.48^{\mathrm{a}}$ & $6.86 \pm 0.26^{\mathrm{c}}$ & $1.99 \pm 0.04^{\mathrm{c}}$ \\
\hline Ether extract & $2.01 \pm 0.08^{\mathrm{b}}$ & $3.96 \pm 0.08^{\mathrm{b}}$ & $0.22 \pm 0.08^{\mathrm{a}}$ \\
\hline Ash & $0.71 \pm 0.05^{\mathrm{c}}$ & $1.80 \pm 0.10^{\mathrm{a}}$ & $1.09 \pm 0.10^{\mathrm{a}}$ \\
\hline Crude fiber & $0.92 \pm 0.08^{\mathrm{c}}$ & $0.38 \pm 0.08^{\mathrm{ab}}$ & $0.59 \pm 0.08^{\mathrm{a}}$ \\
\hline N.F.E.** & $85.00 \pm 0.12^{\mathrm{b}}$ & $87.00 \pm 0.42^{\mathrm{b}}$ & $96.11 \pm 0.12^{\mathrm{a}}$ \\
\hline
\end{tabular}

*On dry weight, ** N.F.E.: nitrogen free extract , Mean value for three samples, \pm Standard deviation ,Means in the same row with different letters are significantly difference at $\mathrm{P} \leq 0.05$.

Polyphenolics from various plant sources are receiving increasing attention due to the desirable physiological functions associated with antioxidant activities (Ishiguro et al., 2007). They prevent oxidative stress that increases risk for many diseases (Hagerman et al., 1998, and Kaul \& Khanduja, 1998).Total phenol content for tested samples is illustrated in Table (3).The data shows that the sweet potato flour had higher contents of total phenol $(13.92 \mathrm{mg} / \mathrm{g})$.

The $\beta$ - carotene and ascorbic acid contents of wheat flour, sweet potato flour, potato flour and sponge cake are presented in Table (4). With the increase in sweet potato flour in sponge cake, the concentration of $B$-carotene in sponge cake increased proportionally. $B$ - Carotene pigments are considered to be a rich source of antioxidant substances (Yamakaw, 1998). Sweet potatoes are rich in carotenoids, especially $B$-carotene, which is basically absent in whole wheat flours and bakery products (Van Hal, 2000).

Ascorbic acid content was found to be $96.67 \mathrm{mg} / 100 \mathrm{~g}$ for sweet potato and was found to be $82.95 \mathrm{mg} / 100 \mathrm{~g}$ in potato flour; this slight difference could be due to the maturity stage according to (Mazza, 1984) who reported that such vitamin content increased with growth and maturity of potato tubers. The lowering of ascorbic acid for sponge cake than flours was propabably because of the thermal degradation during baking of sponge cake.

Fayoum J. Agric. Res. \& Dev., Vol.22, No.2, July, 2008 
Table (3): Total sugars and total phenol contents of sweet potato flour, potato flour and sponge cake*

\begin{tabular}{|c|c|c|c|c|c|c|}
\hline \multirow[b]{2}{*}{ Sample } & \multirow{2}{*}{$\begin{array}{c}\text { Reducing } \\
\text { sugar } \\
\%\end{array}$} & \multirow{2}{*}{$\begin{array}{l}\text { Non- } \\
\text { reducing } \\
\text { sugars } \\
\%\end{array}$} & \multirow{2}{*}{$\begin{array}{c}\text { Total } \\
\text { sugars } \\
\%\end{array}$} & \multicolumn{3}{|c|}{ Phenols (mg/g) } \\
\hline & & & & $\begin{array}{c}\text { Water } \\
\text { extract } \\
(\mathrm{mg} / \mathrm{g})\end{array}$ & $\begin{array}{c}\text { Methanol } \\
\text { extract } \\
(\mathrm{mg} / \mathrm{g})\end{array}$ & $\begin{array}{c}\text { Total } \\
\text { phenol } \\
\text { (mg/g) }\end{array}$ \\
\hline Whe & $0.96 \pm$ & $0.44 \pm 0.23^{\mathrm{c}}$ & $4.50 \pm 0.14^{\mathrm{b}}$ & $0.78 \pm 0.32^{\mathrm{c}}$ & $0.41 \pm 0.09^{\mathrm{a}}$ & $1.19 \pm 0.12^{\mathrm{g}}$ \\
\hline Sweet potato flour (SPF) & $1.89 \pm 0.08^{\mathrm{b}}$ & $2.61 \pm 0.12^{\mathrm{b}}$ & $2.91 \pm 0.06^{\mathrm{c}}$ & $5.51 \pm 0.30^{\mathrm{a}}$ & $8.41 \pm 0.16^{\mathrm{c}}$ & $13.92 \pm 0.10^{\mathrm{a}}$ \\
\hline Potato flour (PF) & $0.99 \pm 0.25^{\mathrm{a}}$ & $28.61 \pm 0.22^{\mathrm{a}}$ & $31.50 \pm 0.12^{\mathrm{a}}$ & $1.31 \pm 0.12^{\mathrm{b}}$ & $5.51 \pm 0.11^{\mathrm{b}}$ & $6.82 \pm 0.01^{\mathrm{c}}$ \\
\hline Sponge cake & & & & & & \\
\hline -control(WF) & $2.89 \pm 0.19^{\mathrm{ab}}$ & $28.72 \pm 0.08^{\mathrm{a}}$ & $31.61 \pm 0.09^{\mathrm{a}}$ & $4.50 \pm 0.09^{\mathrm{b}}$ & $0.76 \pm 0.01^{\mathrm{b}}$ & $5.26 \pm 0.21^{\mathrm{e}}$ \\
\hline -with $10 \%$ SPF & $5.65 \pm 0.12^{\mathrm{c}}$ & $26.36 \pm 0.19^{\mathrm{a}}$ & $32.01 \pm 0.12^{\mathrm{a}}$ & $5.61 \pm 0.24^{\mathrm{a}}$ & $2.30 \pm 0.20^{\mathrm{a}}$ & $7.91 \pm 0.31^{\mathrm{c}}$ \\
\hline -with $20 \%$ SPF & $7.22 \pm 0.90^{\mathrm{c}}$ & $24.48 \pm 0.09^{b}$ & $31.70 \pm 0.17^{\mathrm{a}}$ & $5.75 \pm 0.08^{\mathrm{a}}$ & $3.01 \pm 0.15^{\mathrm{a}}$ & $8.76 \pm 0.06^{\mathrm{b}}$ \\
\hline $40 \% \mathrm{SPF}$ & $8.19 \pm 0.08^{\mathrm{d}}$ & $23.96 \pm 0.31^{\mathrm{b}}$ & $32.15 \pm 0.19^{b}$ & $3.89 \pm 0.19^{c}$ & $3.12 \pm 0.09^{\mathrm{a}}$ & $7.01 \pm 0.12^{\mathrm{c}}$ \\
\hline -wit & $4.50 \pm 0.05^{\mathrm{c}}$ & $27.57 \pm 0.33^{\mathrm{a}}$ & $32.07 \pm 0.01^{\mathrm{b}}$ & $3.62 \pm 0.12^{\mathrm{c}}$ & $1.29 \pm 0.012^{b}$ & $5.91 \pm 0.09^{\mathrm{d}}$ \\
\hline -with & $5.01 \pm 0.11^{\mathrm{c}}$ & $27.07 \pm 0.15^{\mathrm{a}}$ & $32.08 \pm 0.01^{\mathrm{b}}$ & $3.01 \pm 0.09^{c}$ & $1.81 \pm 0.19^{\mathrm{b}}$ & $4.82 \pm 0.01^{\mathrm{f}}$ \\
\hline -with $40 \%$ PF & $6.44 \pm 0.13^{\mathrm{cb}}$ & $26.63 \pm 0.48^{b}$ & $33.07 \pm 0.32^{\mathrm{ab}}$ & $3.51 \pm 0.18 \mathrm{c}$ & $1.89 \pm 0.09^{\mathrm{b}}$ & $5.40 \pm 0.10^{\mathrm{d}}$ \\
\hline
\end{tabular}

Mean value for three samples, \pm Standard deviation, Means in the same column with different letters are significantly difference at $\mathrm{P} \leq 0.05$.

Table (4): B-Carotene and ascorbic acid contents of wheat flour, sweet potato flour, potato flour and sponge cake*

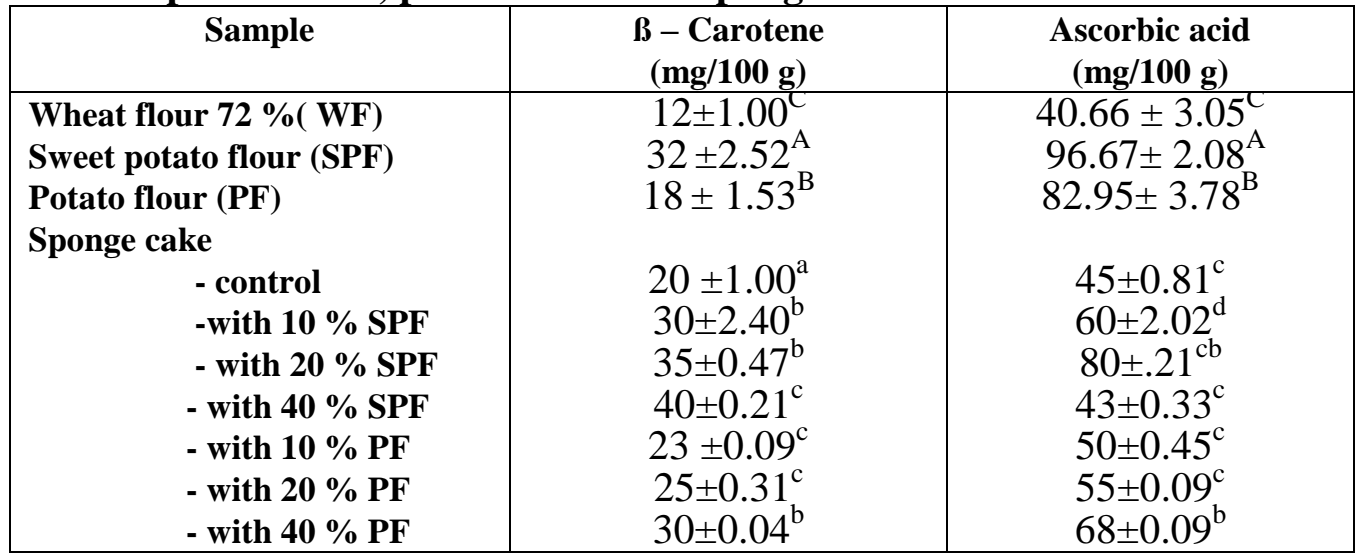

Mean value for three samples, \pm Standard deviation, Means in the same column with different letters are significantly difference at $\mathrm{P} \leq 0.05$.

\section{Gluten content}

The effect of sweet potato and potato flour on the gluten content is shown in Table (5). With the increase in sweet potato and potato flours in sponge cake, the gluten content decreased proportionally. For there this sponge cake can use for decrease the celiac disease (Shih et al., 2006).

Fayoum J. Agric. Res. \& Dev., Vol.22, No.2, July, 2008 
EFFECT OF USING SWEET POTATO AND POTATO FLOURS ON... 171

Table (5): Effect of sweet potato and potato flours on gluten content*

\begin{tabular}{|l|c|}
\hline \multicolumn{1}{|c|}{ Sample } & $\begin{array}{c}\text { Gluten content } \\
(\%)\end{array}$ \\
\hline -Wheat flour72 \%(W.F) & $11.11 \pm 0.096^{\mathrm{a}}$ \\
\hline - W.F with 10 \% SPF & $10.44 \pm .427^{\mathrm{ab}}$ \\
\hline - W.F with 20 \% SPF & $10.54 \pm 0.215^{\mathrm{a}}$ \\
\hline - W.F with 40 \% SPF & $9.06^{ \pm} 0.049^{\mathrm{ca}}$ \\
\hline - W.F with 10 \% PF & $9.70 \pm .098^{\mathrm{bc}}$ \\
\hline - W.F with 20 \% PF & $9.75 \pm 0.91^{\mathrm{bc}}$ \\
\hline - W.F with 40 \% PF & $8.81 \pm 0.86^{\mathrm{d}}$ \\
\hline
\end{tabular}

Mean value for three samples, \pm Standard deviation, Means with different letters are significantly difference at $\mathrm{P} \leq 0.05$.

\section{Rheological characteristics}

The results of the dough properties as affected by sweet potato and potato flours are shown in Table (6). Increase in sweet potato and potato flours content in the blend from 0 to $10 \%$ increased the water absorption from $58.22 \%$ to $63 \%$ and $60.5 \%$ for sweet potato and potato flours, respectively. Dough development time decreased from 2.5 to 2.00 .

The dough stability as an indicator to dough strength decreased in all treatments in comparison to the control (WF). That means that the dough becomes weak due to replacement with either SPF or PF. The effect of sweet potato and potato flours on the elastic properties of the dough are illustrated in Table (7). With the use of sweet potato $10 \%$, the resistance to extension values increased from 700 to $720 \mathrm{BU}$ and extensibility values increased from $120 \mathrm{~mm}$ to $137 \mathrm{~mm}$. But more substitution caused less resistance to extension and also low energy. On the other hand, when the sweet potato and potato flour was increased the proportional No. was decreased. This may be either due to the dilution of gluten proteins or interactions between polysaccharides and proteins from wheat flour as reported by Chen $\boldsymbol{e t}$ al., (1988).

Table (6): Farinograph readings of wheat flour (72 \% ext.) as affected by supplemented with sweet potato and potato flours

\begin{tabular}{|c|c|c|c|c|c|}
\hline & $\begin{array}{c}\text { Water } \\
\text { absorption } \\
(\%)\end{array}$ & $\begin{array}{c}\text { Arrival } \\
\text { time } \\
\text { (min.) }\end{array}$ & $\begin{array}{c}\text { Dough } \\
\text { development } \\
\text { time (min.) }\end{array}$ & $\begin{array}{c}\text { Dough } \\
\text { stability } \\
\text { (min.) }\end{array}$ & $\begin{array}{c}\text { Dough } \\
\text { weakening } \\
\text { B.U }\end{array}$ \\
\hline Wheat flour 72 \%( WF) & 58.20 & 1.50 & 2.50 & 3.50 & 30 \\
\hline W.F+ Sweet potato flour & & & & & \\
$\mathbf{1 0 \%}$ & 63.00 & 1.50 & 2.00 & 1.50 & 30 \\
$\mathbf{2 0 \%}$ & 64.30 & 1.50 & 2.00 & 2.00 & 80 \\
$\mathbf{4 0 \%}$ & 65.00 & 1.50 & 1.50 & 2.00 & 80 \\
\hline W.F +potato flour & & & & & \\
$\mathbf{1 0 \%}$ & 60.50 & 1.50 & 2.00 & 2.00 & 30 \\
$\mathbf{2 0 \%}$ & 61.56 & 1.50 & 2.00 & 1.50 & 40 \\
$\mathbf{4 0 \%}$ & 62.10 & 1.50 & 2.00 & 1.50 & 70 \\
\hline
\end{tabular}

Fayoum J. Agric. Res. \& Dev., Vol.22, No.2, July, 2008 
Table (7): Effect of sweet potato and potato flours on Extensograph parameter

\begin{tabular}{|r|c|c|c|c|}
\hline Samples & $\begin{array}{c}\text { Extensibility } \\
(\mathbf{E}, \mathbf{m m})\end{array}$ & $\begin{array}{c}\text { Resistance of } \\
\text { Extension } \\
(\mathbf{R}, \mathbf{B U})\end{array}$ & $\begin{array}{c}\text { Proportional } \\
\text { number } \\
(\mathbf{R} / \mathbf{E})\end{array}$ & $\begin{array}{c}\text { Energy } \\
(\mathbf{c m})\end{array}$ \\
\hline Wheat flour72 \% (WF) & 120 & 700 & 5.83 & 133.30 \\
\hline W.F+ Sweet potato flour & & & & \\
$\mathbf{1 0 \%}$ & 137 & 720 & 5.25 & 143.80 \\
$\mathbf{2 0 \%}$ & 130 & 500 & 3.83 & 99.70 \\
$\mathbf{4 0 \%}$ & 160 & 530 & 3.31 & 100.50 \\
\hline W.F + Potato flour & 145 & 500 & 3.45 & 159.00 \\
$\mathbf{1 0 \%}$ & 150 & 480 & 3.20 & 146.00 \\
$\mathbf{2 0 \%}$ & 150 & 420 & 2.80 & 111.50 \\
\hline $\mathbf{4 0 \%}$ & & & &
\end{tabular}

Physical properties of cake batter

Analytical measurements results of sponge cake batter are given in Table (8). Data show the specific gravity was decrease by using sweet potato flour at all level of supplementation. In contrary point this property was increased by using potato flour as additives at all level. Density (specific gravity) is usually determined by the ratio of cake batter weight to the weight of distilled water at the same temperature. Specific gravity indicates the ability of proteins to incorporated air into the batter, and it is related to air cell size distribution in baked cakes (Arunepanlop et al., 1996). Differences among the $\mathrm{pH}$ values of cake batters with different levels of substitution were significant at high level of supplementation $(20 \%$ or $40 \%)$ by using either sweet potato or potato flours.

Table (8): Effect of sweet potato and potato flours on the physical properties of sponge cake batter

\begin{tabular}{|c|c|c|}
\hline Sponge cake batter & $\mathbf{p H}$ & Specific gravity (g/cm3 ) \\
\hline Control (W.F 72\%) & $7.12 \pm 0.10^{\mathrm{c}}$ & $0.78 \pm 0.02^{\mathrm{c}}$ \\
\hline W.F+ Sweet potato flour & & \\
$\mathbf{1 0 \%}$ & $7.21 \pm 0.05^{\mathrm{ab}}$ & $0.73 \pm 0.01^{\mathrm{a}}$ \\
$\mathbf{2 0 \%}$ & $7.23 \pm .03^{\mathrm{ab}}$ & $0.74 \pm 0.01^{\mathrm{a}}$ \\
$\mathbf{4 0 \%}$ & $7.26 \pm .01^{\mathrm{a}}$ & $0.74 \pm 0.01^{\mathrm{a}}$ \\
\hline $\mathbf{W . F}+$ Potato flour & & \\
$\mathbf{1 0 \%}$ & $7.17 \pm 0.01^{\mathrm{bc}}$ & $0.85 \pm 0.04^{\mathrm{b}}$ \\
$\mathbf{2 0 \%}$ & $7.22 \pm 0.05^{\mathrm{ab}}$ & $0.87 \pm 0.02^{\mathrm{ab}}$ \\
$\mathbf{4 0 \%}$ & $7.25 \pm 0.01^{\mathrm{ab}}$ & $0.88 \pm 0.07^{\mathrm{a}}$ \\
\hline
\end{tabular}

Mean value for three samples, \pm Standard deviation, Means in the same column with different letters are significantly difference at $\mathrm{P} \leq 0.05$.

Cake volume is used as a criterion to measure the quality of fresh cake in research, quality control in industry and by consumers. As shown in Table (9). The volumes of sweet potato cake ranged from 316 to $467 \mathrm{Cm}^{3}$ insignificant decreasing as level of sweet potato increased. On the other hand there is a significant decreasing as the level of potato flour increase. Some weight loss is

Fayoum J. Agric. Res. \& Dev., Vol.22, No.2, July, 2008 
EFFECT OF USING SWEET POTATO AND POTATO FLOURS ON... 173

inevitable when cake (generally bakery products) is baked because of moisture loss during the baking process. There were slight differences in weight loss among the tested cake samples.

Table (9): Effect of sweet potato and potato flours on physical properties of sponge cake*

\begin{tabular}{|c|c|c|c|c|c|}
\hline Treatments & $\begin{array}{c}\text { Cake volume } \\
\text { (Cm 3) }\end{array}$ & $\begin{array}{c}\text { Cake weight } \\
\text { ( g ) }\end{array}$ & $\begin{array}{c}\text { Specific } \\
\text { volume } \\
(\mathrm{Cm} 3 / \mathrm{g}) \\
\end{array}$ & $\begin{array}{c}\text { Sponge } \\
\text { cake } \\
\text { height }(\mathrm{cm})\end{array}$ & $\begin{array}{c}\text { Baking loss } \\
\%\end{array}$ \\
\hline Control (W.F72\%) & $463 \pm 2.88^{\mathrm{ab}}$ & $123.66 \pm 3.21^{\mathrm{bc}}$ & $3.74 \pm 0.19^{\mathrm{e}}$ & $5.50 \pm 0.21^{\mathrm{a}}$ & $4.77 \pm 0.20^{b}$ \\
\hline \begin{tabular}{|r|} 
Sweet potato flour \\
$10 \%$ \\
$20 \%$ \\
$40 \%$ \\
\end{tabular} & $\begin{array}{l}467 \pm 9.84^{\mathrm{a}} \\
446 \pm 2.88^{\mathrm{b}} \\
455 \pm 5.00^{\mathrm{ab}}\end{array}$ & $\begin{array}{c}121.66 \pm 2.88^{\mathrm{c}} \\
127.00 \pm 1.00^{\mathrm{ab}} \\
124.5 \pm 1.32^{\mathrm{ab}}\end{array}$ & $\begin{array}{c}3.84 \pm 0.25^{\mathrm{cd}} \\
3.51 \pm 0.03^{\mathrm{d}} \\
3.65 \pm 0.52^{\mathrm{bc}} \\
\end{array}$ & $\begin{array}{l}7.50 \pm 0.09^{c} \\
7.00 \pm 0.08^{c} \\
6.90 \pm 0.11^{c} \\
\end{array}$ & $\begin{array}{l}6.41 \pm 0.01^{\mathrm{a}} \\
2.30 \pm 0.32^{\mathrm{d}} \\
4.23 \pm 0.42^{\mathrm{b}} \\
\end{array}$ \\
\hline $\begin{array}{r}\text { Potato flour } \\
\qquad \begin{array}{r}10 \% \\
20 \% \\
40 \%\end{array}\end{array}$ & $\begin{array}{l}383 \pm 10.40^{c} \\
371 \pm 16.44^{c} \\
316 \pm 15.27^{d}\end{array}$ & $\begin{array}{c}125.50 \pm 2.29^{\mathrm{abc}} \\
126.73 \pm 1.50^{\mathrm{ab}} \\
128.16 \pm 1.04^{\mathrm{a}}\end{array}$ & $\begin{array}{l}3.05 \pm 0.06^{\mathrm{b}} \\
2.93 \pm 0.17^{\mathrm{b}} \\
2.46 \pm 0.15^{\mathrm{c}}\end{array}$ & $\begin{array}{l}6.20 \pm 0.19^{\mathrm{b}} \\
6.00 \pm 0.20^{\mathrm{b}} \\
5.90 \pm 0.14^{\mathrm{a}}\end{array}$ & $\begin{array}{l}3.46 \pm 0.08^{\mathrm{c}} \\
2.51 \pm 0.09^{\mathrm{d}} \\
1.41 \pm 0.01^{\mathrm{e}}\end{array}$ \\
\hline
\end{tabular}

Mean value for three samples, \pm Standard deviation, Means in the same column with different letters are significantly difference atP $\leq 0.05$.

\section{Proximate composition of sponge cake}

The proximate composition of the sponge cake supplemented with sweet potato and potato flours is shown in Table (9), where it could be noticed that the chemical composition of sponge cake was affected by the addition of sweet potato and potato flours. Ash, crude fiber and N.F.E. were increased in sponge cake.

Table (10): Chemical composition of sponge cake with sweet potato and potato flours*

\begin{tabular}{|c|c|c|c|c|c|c|}
\hline Treatments & $\begin{array}{c}\text { Moisture } \\
\text { \% }\end{array}$ & $\begin{array}{c}\text { Protein } \\
\text { \% }\end{array}$ & $\begin{array}{c}\text { Ether } \\
\text { extract\% }\end{array}$ & $\begin{array}{c}\text { Ash } \\
\text { \% }\end{array}$ & $\begin{array}{c}\text { Crude fiber } \\
\%\end{array}$ & N.F.E.* \% \\
\hline $\begin{array}{c}\text { Control (W.F) } \\
\mathbf{7 2 \%}\end{array}$ & $26.23 \pm 0.25^{\mathrm{f}}$ & $13.7 \pm 0.26^{\mathrm{a}}$ & $1.05 \pm 0.04^{\mathrm{ab}}$ & $0.52 \pm 0.03^{\mathrm{c}}$ & $0.56 \pm 0.01^{\mathrm{c}}$ & $83.65 \pm 0.01^{\mathrm{d}}$ \\
\hline $\begin{array}{r}\text { Sweet potato flour } \\
\mathbf{1 0 \%}\end{array}$ & $27.10 \pm 0.18^{\mathrm{d}}$ & $10.03 \pm 0.06^{\mathrm{bc}}$ & $1.03 \pm 0.05^{\mathrm{b}}$ & $0.57 \pm 0.09^{\mathrm{ab}}$ & $0.6 \pm 0.09^{\mathrm{b}}$ & $86.32 \pm 0.12^{\mathrm{b}}$ \\
$\mathbf{2 0 \%}$ & $28.16 \pm 0.25^{\mathrm{b}}$ & $10.63 \pm 0.23^{\mathrm{b}}$ & $1.13 \pm 0.05^{\mathrm{a}}$ & $0.66 \pm 0.23^{\mathrm{ab}}$ & $0.69 \pm 0.18^{\mathrm{a}}$ & $85.49 \pm 0.20^{\mathrm{c}}$ \\
$\mathbf{4 0 \%}$ & $30.10 \pm 0.01^{\mathrm{a}}$ & $9.60 \pm 0.73^{\mathrm{c}}$ & $0.90 \pm 0.01^{\mathrm{c}}$ & $0.71 \pm 0.09^{\mathrm{a}}$ & $0.72 \pm 0.13^{\mathrm{a}}$ & $86.63 \pm 0.15^{\mathrm{b}}$ \\
\hline & & & & & \\
$\mathbf{1 0 \%}$ & $26.47 \pm 0.45^{\mathrm{ef}}$ & $9.54 \pm 0.38^{\mathrm{c}}$ & $0.86 \pm 0.06^{\mathrm{c}}$ & $0.63 \pm 0.12^{\mathrm{ab}}$ & $0.59 \pm 0.23^{\mathrm{a}}$ & $88.03 \pm 0.30^{\mathrm{a}}$ \\
$\mathbf{2 0 \%}$ & $26.80 \pm 0.20^{\mathrm{de}}$ & $9.81 \pm 0.18^{\mathrm{c}}$ & $0.86 \pm 0.04^{\mathrm{c}}$ & $0.68 \pm 0.19^{\mathrm{a}}$ & $0.61 \pm 0.09^{\mathrm{b}}$ & $87.59 \pm 0.05^{\mathrm{ab}}$ \\
$\mathbf{4 0 \%}$ & $27.60 \pm 0.35^{\mathrm{c}}$ & $9.37 \pm 0.04^{\mathrm{c}}$ & $0.84 \pm 0.05^{\mathrm{c}}$ & $0.70 \pm 0.10^{\mathrm{a}}$ & $0.64 \pm 0.08^{\mathrm{b}}$ & $87.97 \pm 0.06^{\mathrm{a}}$ \\
\hline
\end{tabular}

*On dry weight, ** N.F.E.: nitrogen free extract' Mean value for three samples, \pm Standard deviation ,Means in the same column with different letters are significantly difference at $\mathrm{P} \leq$ 0.05 .

Fayoum J. Agric. Res. \& Dev., Vol.22, No.2, July, 2008 
Fayoum J. Agric. Res. \& Dev., Vol.22, No.2, July, 2008 


\section{Organoleptic evaluations of sponge cakes}

As a matter of fact, organoleptic properties are the final guide to the quality from the consumer point of view. Therefore, the application of the sweet potato flour and potato flour was carried out on sponge cake to investigate their effect on sensory properties. The sensory results of sponge cake are presented in Table (11). The sensory results of sponge cakes showed that the effect of sweet potato flour on sponge cake was insignificant. Though the overall quality scores reduce, the cakes prepared from $10 \%$ sweet potato was highly acceptable. The flavor of bakery products is a result of the aroma compounds produced by enzymatic, fermentative and thermal reaction of sugar and starch during baking and the aroma compounds deliberately added to the products to obtain baked goods with specific aromatic characteristics. (Pozo- Bayoyon et al., 2007).

Table (12): Changes of water content in sponge cakes supplemented with sweet potato and potato flours during storage

\begin{tabular}{|c|c|c|c|c|c|c|c|}
\hline \multirow{2}{*}{\begin{tabular}{c} 
Storage period $\begin{array}{c}|c| \\
\text { (Day) }\end{array}$ \\
\cline { 3 - 8 }
\end{tabular}} & Control & \multicolumn{3}{|c|}{ Sweet potato flour } & \multicolumn{3}{c|}{ Potato flour } \\
\cline { 2 - 8 } & & $\mathbf{1 0 \%}$ & $\mathbf{2 0 \%}$ & $\mathbf{4 0 \%}$ & $\mathbf{1 0 \%}$ & $\mathbf{2 0 \%}$ & $\mathbf{4 0} \%$ \\
\hline $\mathbf{0}$ & 38.11 & 38.40 & 38.90 & 39.70 & 35.22 & 35.91 & 36.50 \\
\hline $\mathbf{2}$ & 37.30 & 37.70 & 38.01 & 39.1 & 33.90 & 34.66 & 35.01 \\
\hline $\mathbf{4}$ & 34.12 & 36.01 & 37.50 & 38.2 & 32.11 & 31.01 & 32.06 \\
\hline $\mathbf{6}$ & 30.21 & 35.41 & 36.20 & 37.30 & 28.61 & 29.01 & 30.11 \\
\hline $\mathbf{8}$ & 27.11 & 34.70 & 35.81 & 36.55 & 25.66 & 25.99 & 32.22 \\
\hline $\mathbf{1 0}$ & 22.01 & 31.11 & 34.91 & 35.99 & 23.06 & 23.19 & 29.60 \\
\hline
\end{tabular}

* Mean value for three samples.

\section{Effect of storage on water content of sponge cakes}

During storage studies, sponge cakes supplemented with sweet potato and potato flour were analyzed for moisture content, and the results are presented in (Table 12). As expected, all samples showed a definite decrease in crumb moisture content during 10 days of storage.

The moisture content was decreased from $38.11 \%$ to $22.01 \%, 38.4 \%$ to $31.11 \%$ and from $35.22 \%$ to $23.06 \%$ for control, sponge cake supplemented with $10 \%$ sweet potato flour and potato flour, respectively. In the course of storage, the moisture migrates from the crumb toward the crust and evaporates from the surface of the product (Piozza \& Masi, 1995).

Effect of storage the supplemented sponge cake on total microbial count

The total microbial counts of different supplemented cakes under investigation were followed up directly after preparation and during the storage time at room temp. $\left(35 \pm 2{ }^{\circ} \mathrm{C}\right)$, to assess one of the most important factors in evaluation of sponge cake, i.e., safety and quality. The obtained data are presented in Table (13). From these results, it could be observed that substitution of sweet potato $(10 \%, 20 \%$ and $40 \%)$ inhibited mold and yeast growth during the first six days of storage at room temp. In contrast, the control sponge cake spoiled after just 2 days. The inhibitory effect of sweet potato and potato flours

Fayoum J. Agric. Res. \& Dev., Vol.22, No.2, July, 2008 
was mentioned by (Moreno et al., 1994, and Huang et al., 2008). Concerning total yeast and mold counts, substitution of wheat flour with sweet potato and potato flours (at different levels) gave completely growth inhibition up to 10 days at room temp. $\left(35 \pm 2{ }^{\circ} \mathrm{C}\right)$, and then a slight growth of fungi was recorded from the 11 day of storage for cakes with $10 \%$ sweet potato and $20 \%$ potato flours; this may be attributed to starch and the low moisture content in addition to the high content from total phenols.

Table (13): Total bacterial and fungal counts (CFU) of sponge cake substituted with sweet potato and potato flours during storage at room temp. $\left(35 \pm 2{ }^{\circ}\right.$ ) for 10 days.

\begin{tabular}{|c|c|c|c|c|c|c|c|c|c|c|c|c|}
\hline \multirow{3}{*}{$\begin{array}{c}\text { Sponge cake } \\
\text { sample }\end{array}$} & \multicolumn{12}{|c|}{ Storage period (days) } \\
\hline & \multicolumn{2}{|c|}{$\mathbf{0}$} & \multicolumn{2}{|c|}{2} & \multicolumn{2}{|c|}{4} & \multicolumn{2}{|c|}{6} & \multicolumn{2}{|c|}{8} & \multicolumn{2}{|c|}{10} \\
\hline & TBC & F\&M & TBC & F\&M & TBC & F\&M & TBC & F\&M & TBC & F\&M & TBC & F\&M \\
\hline Control(W.F) & 0 & 0 & 0 & 0 & 32 & 0 & 60 & 10 & 125 & 20 & 160 & 35 \\
\hline Sponge & & & & & & & & & & & & \\
\hline$-10 \%$ SPF & 0 & 0 & 0 & 0 & 0 & 0 & 0 & 0 & 15 & 5 & 25 & 8 \\
\hline$-20 \%$ SPF & 0 & 0 & 0 & 0 & 0 & 0 & 0 & 0 & 18 & 4 & 30 & 7 \\
\hline$-40 \%$ SPF & 0 & 0 & 0 & 0 & 0 & 0 & 0 & 0 & 20 & 4 & 20 & 5 \\
\hline$-10 \% \mathrm{PF}$ & 0 & 0 & 0 & 0 & 0 & 0 & 0 & 0 & 30 & 12 & 40 & 16 \\
\hline$-20 \% \mathrm{PF}$ & 0 & 0 & 0 & 0 & 0 & 0 & 0 & 0 & 38 & 8 & 35 & 17 \\
\hline$-40 \% \mathrm{PF}$ & 0 & 0 & 0 & 0 & 0 & 0 & 0 & 0 & 33 & 9 & 35 & 14 \\
\hline
\end{tabular}

TBC: Total bacterial count

F\&M: Fungi and mold count

\section{Conclusions}

The results showed that the use of sweet potato and potato flours in partial replacement of wheat flour $(20 \%)$ could significantly affect sponge cake in a desirable way and can reduce the quantity of wheat flour. This offers opportunities to efficiently use sweet potato and potato flours in the manufacture of sponge cake. Sweet potato (with skin) flour has potential for use in cake making as a good source of poly phenols which has antioxidant properties.

\section{REFERENCES}

A.O.A.C. (2000). Official Methods of Analysis of the Association of Official Analytical Chemists. 17 ed.Gaithersburg, Maryland. USA.

AACC, (2000). Approved methods of the AACC $\left(10^{\text {th }}\right.$ ed). St Paul, MN: American Association of Cereal Chemists (Methods 08-01, 30-25, 4415A, 46-10, 54-10, 54-21).

Afoakwa, E. O. and Sefa- Dedeh, S. (2001). Chemical composition and quality changes occurring in Dioscorea dumetorum Pax tubers after harvest. Food Chem., 75:85-91.

Arunepanlop, B., Morr, C.V. Karleskind, D., and Laye, I. (1996). Partial replacement of egg white proteins with whey proteins in angel food cakes. J. of Food Science. 61 (5): 1085-1093.

Fayoum J. Agric. Res. \& Dev., Vol.22, No.2, July, 2008 
EFFECT OF USING SWEET POTATO AND POTATO FLOURS ON... 177

Bo'hm, F., Edge, R., Land, E., McGrvey, D., and Truscott, G., (1997). Carotenoids enhance vitamin $\mathrm{E}$ antioxidant efficiency J. Am. Chem.,Soc., 119:621-622.

Cambie,R. C. and Ferguson, L. R. (2003). Functional foods in the traditional Maori diet. Mutat . Res., 523-524, 109-118.

Celic, I., Yilamz, Y.; Isik,F. and Ustun, O. (2007). Effect of soapwort extract on physical and sensory properties of sponge cake and rheological properties of sponge cake batters. Food Chem. 101:907-911.

Cevallos - Casals, B.A. and Cisneros-Zevallos, L. (2003). Stoichiometric and kinetic atudies of phenolic antioxidants from Andean purple corn and red-fleshed sweet potato. J. Agric. Food Chem, 51(11): 3313-3319.

Chen, H., Rubenthaler, G.L., and Schanus, E.G. (1988). Effect of apple fiber and cellulose on the physical properties of wheat flour. Journal of Food Science, 53:304-305.

Duncan, D.B. (1955). Multiple ranges and multiple F Test. Biometrics, 11: 1-42.

Fasano, A. and Catassi, C. (2001). Current approaches to diagnosis and treatment of celiac disease: An evolving spectrum. Gastroentrology. 120:636-651.

Feighery, C.F. (1999). Coeliac disease. BMJ, 319, 236-239.

Guan, Y., Wu, T. Lin, M. and Jiannong, Y. (2006). Determination of pharmacologically active Ingredients in sweet potato (Ipomoea batatas L.) by Capillary Electrophoresis with Electrochemical Detection. J. Agric. \& Food Chem., 54: 24-28.

Hagerman, A.E., Riedl, K.M., Jones, G.A., Sovik, K.N., Ritchard, N.T, Hartzfeld, P.W., Riechel, T.l. (1998). High molecular weight plat polyphenolics (tannins) as biological antioxidants. J. Agric. Food Chem., 46: 1887-1892.

Hsu, C. Hurang, S., Chen, W., Weng, Y. and Tseng, C. (2004). Qualities and antioxidant properties of bread as affected by the incorporation of yam flour in the formulation. International J. Food Sci. \& Tech., 39:231238.

Huang, G.; Lai, H., Chang, Y.; Sheu, M.; Lu, T. Huang, S., and Lin, Y. (2008). Antimicrobial, dehydroascorbate reductase, and mono dehydroascorbate reductase activities of defensin from sweet potato (Ipomoea batatas L.) Lam.' Tainong 57 ' Storage Roots. J. Agric. Food Chem., 56: 2989-2995.

Ishiguro, K., Toyama, J., Islam,M.S., Yoshimoto, M. Kumagai, T. Kai, Y., Nakazawa, Y. Yamakawa, O. (2004). A new sweet potato cultivar for utilization in vegetable green. Acta Hortic. 637: 339-345.

Jansson, R.K. and Raman, K.V. (1991). Sweet potato pest management: A global overview. In Sweet Potato Pest Management: A Global Perpective; Jansson, R.K., Raman, K.V., Eds; Westview Press: Boulder, CO, pp 1-12.

Julseth , R.M. and Deible, R.H.(1974). Microbial profile of selected spices and herbs at import. J. Milk food Technol., 37(8):414-420.

Fayoum J. Agric. Res. \& Dev., Vol.22, No.2, July, 2008 
Kaul , A. and Khanduja, K.L. (1998). Polyphenol inhibit promotional phase of lumorigenesis: relevance of superoxide radicals. Nutr. Cancer, 32:8185.

Kays, S.J. and Kays, S.E. (1998). Sweet potato chemistry in relation to health. In: proceeding of international workshop on sweet potato production system towords the $21^{\text {st }}$ Century (edited by D.R. LaBonte, M. Yamashita \& H. Machida). pp 231-272. Miyakonojo: Kyushu National Agriculture Experiment Station (KNAES).

Lee, C.C. and Hoseney, R.C. (1882). Optimization of the fat - emulsifier system and the gum- egg white -water system for all laboratory scale single-stage cake mix . Cereal Chemistry, 59(5): 392-396.

Matsui, T., Ebuchi, S., Kobayashi, M.; Fukui, Sugita, K.; and Terahara, N. Matsumoto, K. (2002). Anti-Hyperglycemic effect of diacylated anthocyanin derived (Ipomoea batatas) cultivar ayamursaki can be achieved through the $\alpha$ - glucosidase inhibitory action. J. Agric. Food Chem., 50 (25): 7244-7248.

Mayne, S. T. (1996). ß-Carotenoids and disease prevention in humans. The FASEB Journal, $10: 690-701$.

Mazza, G. (1986). Changes in processing quality parameters of potatoes during maturity and long - term storage. Engineering and Food, Vol. 1, Engineering Scieeces, in the food industry pp.351-365 .C.F. FSTA (1989) Vol.18, No. 4, 4J109.

Moreno, M., Segura, A. and Gavcia- Olmedo, F. (1994). Psedothionin-St1,a potato peptide active against potato pathogens. Eur. J. Biochem., 223: $135-139$.

Mostafa, M. K. (1976). Parboiling of wheat, enrichment, and improvement of wheat flour for bread making. Ph.D.thesis Food Sci.,Fac., of Agric.,Ain Shams University.

Oki, T.; Masuda, M.; Furuta, S.; Nishiba, Y.; Terahara,N. and Suda, I. (2002). Involvement of anthocyanins and other phenolic copounds in radical- scavenging activity of purple- flashed sweet potato cultivars. J.Food Sci., 67(5): 1752-1756.

Piazza,L. and Masi, P. (1995). Moisture distribution throughout the bread loaf during staling and its effect on mechanical properties. Cereal Chem., 73:320-325.

Pozo-Bayon, M. A., Ruiz-Rodriguez, A., Pernin, K. and Cayot, N. (2007). Influence of eggs on the aroma composition of sponge cake and on the aroma release in model studies on flavored sponge cakes. J. Agric. Food Chem., 55:1418-1426.

Ray, R.C. and Ravi, V. (2005). Post harvest spoilage of sweet potato in tropics and control measures. Critical review of food science nutrition. 45:623644.

Ray, R.C. and Ward, O.P. (2006). Post harvest microbial biotechnology of tropical roots and tuber crops. In: Microbial Biotechnology in Horticulture (edited by R.C. Ray \& O.P Ward pp. 345-395. Enfield, NH: Science Publisher.

Fayoum J. Agric. Res. \& Dev., Vol.22, No.2, July, 2008 
EFFECT OF USING SWEET POTATO AND POTATO FLOURS ON... 179

Shih, F.F., Truong, V.D. and Daigle, K.W. (2006). Physicochemical properties of glutein - free pancake from rice and sweet potato flours. J. food quality. 29: 97-107.

Singleton, V.L., Orthfofer, R. and Lamuela- Raventos, R.M. (1999). Analysis of total phenols and other oxidation substrates and antioxidants by means of Folin- Ciocalteau reagent . Methods Enzymology. 299: 152178.

SPSS (1999). Statistical Software Package for the Social Sciences. SPSS, Int., USA.

Tian, S.J.; Richard, J.E. and Blanshard, J.M.V. (1991). Physicochemical properties of sweet potato starch. J. Sci. Food Agric., 57: 459-491.

Van Hal, M., V. (2000). Quality of sweet potato flour during processing and storage. Food Rev., Int., 16:1-37.

Woolfe, J.A. (1992). Sweet potato- Past and present. In Sweet Potato: An Untapped Food Resource; Cambridge University Press: Cambridge, United Kingdom, pp 15-40

Woolke, J.A. (1990). Sweet potato: An untapped food resource. pp 643. Cambridge: Cambridge University Press. U.K.

Yamakwa, O. (1998). Development of new cultivation and utilization system for sweet potato towards the $21^{\text {st }}$ century. In: proceedings of international workshop on sweet potato production system towards the $21^{\text {st }}$ century (edited by D.R. Labonte, M Yamashita \& H Machida). pp. 1-8. Miyakonojo: Kyushu National Agriculture Experiment Station (KNAES)

Yin, Y., Li, Y. and Kong, L., (2008). Pentasaccharide, Glycosides from the tubers of sweet potato (Ipomoea batatas). J. Agric. Food Chem., 56: 2363-2368.

Yoshimoto, M. (2001). New trends of processing and use of sweet potato in Japan. Farming J. pn., 35: 22-28.

Yoshimoto, M. Okuno, S., Yamaguchi, M. and Yamakawa, O. (2001). Antimutagenicity of deacylated anthocyanins in purple- fleshed sweet potato. Biosci., Biotechnol., Biochem., 65: 1652-1655.

Yoshimoto, M. Okuno, S., Yoshinaga, M., Yamakawa, O., Yamaguchi, M. and Yamada, J. (1999). Antimutagenicity of sweet potato (Ipomoea batatas) roots. . Biosci., Biotechnol.,Biochem., 63:537- 541.

Zhan, P.X. (1996). Study on antioxidant activity of extracts from sweet potato and potato. Food Ferment. Ind., 2: 30-33.

Fayoum J. Agric. Res. \& Dev., Vol.22, No.2, July, 2008 
تأثير إستخدام دقيق البطاطا والبطاطس على الخصائص الطبيعيه والكيميائيه والحسيه للكيك الإسفنجى

$$
\text { قسم علوم وتكنولوجيا الأغذية- كلية الزبر اعبد الباقي - جامعة الفيوم - مصر }
$$

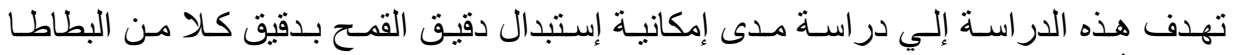

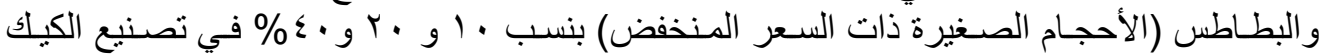

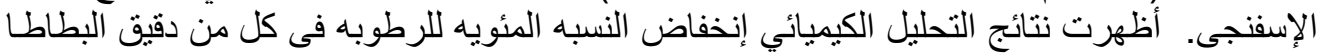
و البطاطس مقارنة بدقيق القمح.

وجد أيضـا أن نسبة الكاروتين في دقيق البطاطا أعلى من دقيق البطاطس و القهـح. لوحظ زيـادة

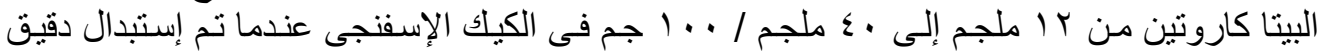

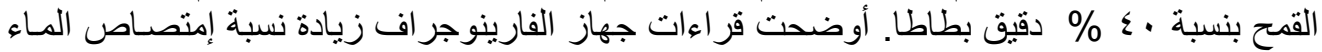

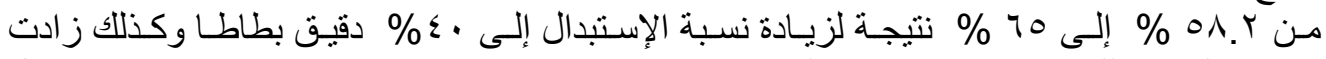

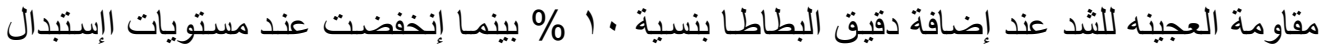

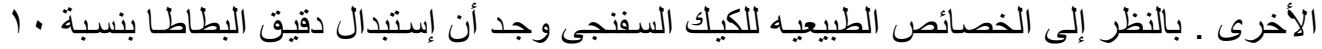

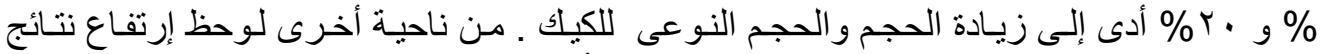

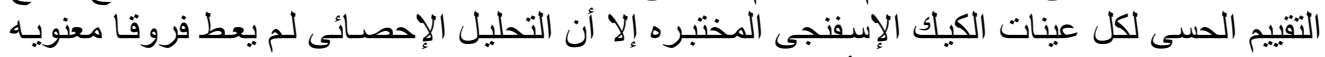

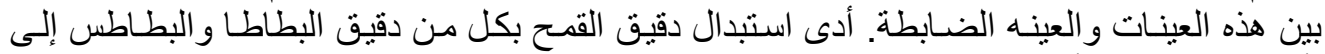
تأثثير مثبط النمو الأحياء الدقيقه خلال فترة التخزين التخين.

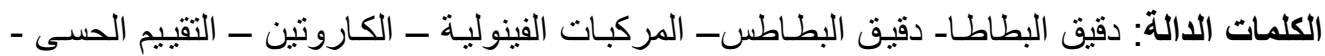

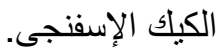

Fayoum J. Agric. Res. \& Dev., Vol.22, No.2, July, 2008 